\title{
PROPERTIES OF I-BOUNDARY LENGTHENING OF VOWELS IN ENGLISH AND SERBIAN**
}

Phonological features which signal the right IP edge include boundary tones and preboundary lengthening. However, languages differ in the prominence of these features. While in English final information focus has significant F0 prominence on PWd immediately preceding I-boundary, Serbian primarily relies on durational cues to signal final information focus and, thus, the right IP edge. This research aims at analyzing the degree and scope of I-boundary lengthening in English and Serbian as well as examining whether there is a compensatory relation between F0 prominence and pre-boundary lengthening in these languages. The research is part of a larger-scale corpus study involving approximately one hour of read speech per language. Both English and Serbian speakers were professional newsreaders and the recordings were comparable in terms of articulation rate and recording quality. The acoustic analysis involved measuring the degree and scope of lengthening in trisyllabic PWds, which was done in the Praat programme (version 6.0.52). The results of the measurements were statistically analyzed. The results of the analysis primarily point to the differences in the scope of I-boundary lengthening in English and Serbian. While the scope of lengthening in Serbian affects the stressed vowel of IP-final PWd as well as all the vowels following it, English postaccented non-final unstressed vowels are skipped by this process. Accordingly, wider scope of lengthening might suggest slightly higher significance of this process in Serbian,

\footnotetext{
*bojana.jakovljevic@ff.uns.ac.rs

** The study was financed by the Ministry of Education, Science and Technological Development of the Republic of Serbia under the Research grants TR32035 and OI178002 and the project Central Audio Library of the University of Novi Sad (CALUNS), funded by the Provincial Secretariat for Higher Education and Scientific Research, AP Vojvodina. The findings reported in this paper were originally presented at the $5^{\text {th }}$ International Conference English Language and Anglophone Literatures Today (ELALT 5), March 9, 2019, Novi Sad, Serbia. Also, they represent part of the PhD corpus-based study of temporal properties of boundary segments of prosodic units in English and Serbian, which is in its final stage.
} 
which can further be interpreted as a compensation for low F0 prominence at the right IP edge in this language.

Key words: pre-boundary lengtening, Intonantional Phrase (IP), prosodic word (PWd), prosody-syntax interface, English, Serbian, acoustic analyis

\section{INTRODUCTION}

According to $\pi$-gesture model (Byrd - Saltzman, 2003), the process of preboundary lengthening (also referred to as 'final lengthening') results from slowing down the articulatory movements, and consequently, the speech tempo while approaching the prosodic boundary, thus signaling the right prosodic edge. Considering the cumulative nature of this process and the fact that it increases over time, the slowest articulatory movements are associated with the prosodic boundary itself. For this reason, the process of pre-boundary lengthening most often affects the rhyme of the final syllable in front of prosodic boundary.

The studies conducted in many languages have shown that the degree of pre-boundary lengthening depends on the depth of prosodic boundary and, accordingly, increases from Prosodic Words (PWds) to Phonological Phrases (PhPs) (also referred to as 'Intermediate Phrases' or 'Major Phrases') and Intonational Phrases (IPs), where it tends to be the highest (Wightman - ShattuckHufnagel - Ostendorf \& Price, 1992 for English; Horne - Strangert \& Heldner, 1995 for Swedish; Cambier-Langeveld - Nespor \& van Heuven, 1997 for Dutch) ${ }^{1}$. Some authors go so far as to suggest the degree of pre-boundary lengthening is sufficient to distinguish the complexity of prosodic constituents, i.e. the constituents of Prosodic Hierarchy (Wightman et al., 1992). Considering that the degree of preboundary lengthening tends to be the highest in IPs, most studies focus on Iboundary lengthening.

In order to describe the process of pre-boundary lengthening in a given language, it is necessary to examine its degree and its scope.

\footnotetext{
${ }^{1}$ Although the terms 'Phonological Phrase', 'Intermediate Phrase' and 'Major Phrase' are not absolutely the same, they are often used interchangeably and the use of the term primarily depends on the author. The term 'Phonological Phrase' is used by Nespor - Vogel (1993) and Selkirk (1984, 1986), the term 'Intermediate Phrase' (ip) by Beckman Pierrehumbert (1986), whereas Elordieta - Frota \& Vigário (2005) use the term 'Major Phrase'.
} 
Although there is no uniform study on I-boundary lengthening (or preboundary lengthening in general), the studies conducted in most languages point to the following universal properties of this process:

- The highest degree of I-boundary lengthening is related to the rhyme of the final unstressed syllable in front of I-boundary;

- The degree of lengthening increases with the strength of prosodic boundary;

- The degree of lengthening of both vowels and consonants depends on their inherent duration;

- The degree of lengthening often depends on the presence of the following pause, i.e. it tends to be higher if IP is followed by a pause, which has been shown in a number of languages (Wightman et al., 1992 in English; Horne et al., 1995 in Swedish; Chow, 2008 in Cantonese).

Also, languages most often differ with respect to the scope of lengthening. Although the rhyme of the final unstressed syllable in front of I-boundary is most prone to lengthening, the analysis of this process in some languages such as English (Shattuck-Hufnagel - Turk, 1998; Turk - Shattuck-Hufnagel, 2007), German (Kohler, 1983), Russian (Volskaya - Stepanova 2004) and Hebrew (Berkovitz, 1994), have shown that the process of lengthening starts on the last stressed syllable of PWd in front of I-boundary, where it is the lowest, and finishes on the last unstressed syllable, where it is the highest, whereas the syllables in between, if present, do not undergo this process. On the other hand, in Japanese (Shepherd, 2008), this process is associated only to the rhyme of the final syllable in front of Iboundary. Finally, there are languages, such as Dutch, where the scope of this process depends on the strength of the vowel in the final syllable rhyme, i.e. if the final vowel is $/ \partial /$, which cannot lengthen due to the minimal articulatory effort, the lengthening is transferred to the rhyme of the preceding syllable (CambierLangeveld et al., 1997).

Still, despite its presence and significant phonological implications in various languages, the phenomenon of pre-boundary lengthening has still been understudied in Serbian. It has been shown that it affects the duration of both initial stressed and final unstressed vowels (Ivić - Lehiste 1996: 235-241). However, the scope of lengthening, i.e. whether this process affects the syllables in between, as well as the lengthening of coda consonants have not been examined yet. On the other hand, this process has been thoroughly examined in English, although the results regarding the scope of lengthening in English tend to be rather contradictory. 
While some authors suggest that this process primarily affects the rhyme of wordfinal $^{2}$ syllable in front of higher prosodic boundaries (Oller 1973; Klatt 1975; Klatt 1976; Wightman et al., 1992), others insist that pre-boundary lengthening starts earlier, i.e. on the rhyme of the last stressed syllable in front of prosodic boundary (Shattuck-Hufnagel - Turk, 1998; Turk - Shattuck-Hufnagel, 2007).

\section{RESERACH GOALS}

Pre-boundary lengthening is only one phonological cue which signals Iboundary. Phonological features which are considered as I-boundary markers also include boundary tones, optional pitch reset in the following IP as well as optional presence of pauses (Wang - Hirschberg, 1992; Ladd 1996; Godjevac, 2000; Godjevac, 2005; Selkirk, 2005). However, languages differ with respect to the prominence of these features. In English, IPs with final information focus are characterized by significant F0 prominence of the last PWd in front of I-boundary (Cruttenden 1986; Ladd 1996). On the other hand, Serbian relies on durational cues, whereas F0 prominence tends to be unreliable (Sredojević, 2011). Accordingly, this research aims at analyzing the degree and scope of I-boundary lengthening in English and Serbian. ${ }^{3}$ The ultimate goal is to examine the relation between F0 prominence and lengthening, both being the markers of the right IP edge or, more precisely, to examine if these two I-boundary cues are directly or inversely proportional.

\section{RESEARCH METHODOLOGY}

The research is part of a larger-scale corpus study aimed at examining temporal properties of boundary segments of prosodic units. It involves

\footnotetext{
${ }^{2}$ The term 'word' refers exclusively to prosodic word (PWd) in this paper.

${ }^{3}$ Despite numerous research works on pre-boundary lengthening in English (see Section 1), the most detailed corpus study of this process was performed only by Wightman et al. (1992). Regarding that the results of this research provide normalized duration values for four speakers, it was necessary to obtain quantitative data so that the results for English and Serbian would be comparable. In addition, Wightman et al. (1992) examine a relatively small set of properties of pre-boundary lengthening in English. In order to get a fuller and more precise picture of how this process operates in English and Serbian, a much more detailed corpus analysis had to be conducted in the same conditions and by using the same methodology in both languages.
} 
approximately one hour of read speech per language. Both the English and Serbian speaker are professional newsreaders. The recordings are comparable in terms of articulation rate $(\mathrm{p}<0.001)$, topics and recording quality, i.e. sampling rate was 44.1 $\mathrm{kHz}$. Also, both in the English and Serbian speech corpus, the articulation rate was within the scope of normal articulation rate for read speech, which is, according to Goldman-Eisler (1961), in the range from 4.4 to $5.9 \mathrm{syl} / \mathrm{sec}$.

We analyzed vowel lengthening in trisyllabic PWds, as defined in formal approaches to prosody and syntax-prosody interface, i.e. stressed words combined with clitics. While in English only leftward cliticization is allowed and the weak forms of function words are treated as clitics only if the weak form is not caused by syntax, i.e. the presence of empty categories (see Inkelas - Zec, 1993; Selkirk 1996), in Serbian both leftward and rightward cliticizations are possible as long as the host is available (see Zec, 2002). As for I-boundaries, we relied on prototypical phonological I-boundary cues mentioned above, i.e. boundary tones, (optional) pitch reset, (optional) presence of pauses, and pre-boundary lengthening itself when it was perceptually salient. In addition, we relied on syntactic cues, primarily in determining I-boundaries in Serbian. Due to the second-position rule for clitics in IP domain, the syntactic structures which are typically realized as IPs, besides clauses, include appositives, parentheticals, heavy constituents and tropicalized elements (see Marković - Milićev 2012).

The acoustic analysis was done in the Praat software (Boersma-Weenink, 2019). It involved measuring the duration of vowels in PWds in IP non-final and IPfinal position and then deriving the degree of final lengthening. In order to achieve uniformity, all the analyzed IPs had final information focus and all the analyzed samples had the same number of IPs with a pause and without a pause on their right edge. We considered only the pauses $\geq 100 \mathrm{~ms}$ due to the fact that it is the lower limit of pause duration in read speech (Campione - Véronis, 2002). Finally, we considered only IPs with falling intonation, which were dominant both in the English and Serbian corpus. The results of the measurements were statistically analyzed.

\section{RESULTS OF THE RESEARCH}

\subsection{I-boundary lengthening of English vowels}

Considering that that the final syllable rhyme is unmarked lengthening position, we first analyzed the lengthening of word-final post-accented vocalic realizations. Word-final vowels were analyzed in closed syllables, where they were 
followed by both voiced and voiceless consonant as well as in open syllables. Both short and long vowels were analyzed. In the latter case, the vowels had either secondary or tertiary stress. However, the distinction between long monophthongs and diphthongs was not made due to the fact that there were not enough examples with long monophthongs word-finally, which made diphthongs dominant. ${ }^{4}$ The results of the research show statistically significant lengthening of all vocalic realizations (Table 1). Also, the degree of lengthening is directly proportional to vowel duration. Long vowels tend to lengthened more than short vowels both in closed and open syllables. In addition, the degree of pre-boundary lengthening is the most prominent in open syllables, less in syllables with a voiced coda consonant, and yet less in those with a voiceless coda consonant. ${ }^{5}$

Table 1: Duration of English post-accented word-final vowels IP-finally and IP non-finally (ms) and the degree of pre-boundary lengthening

\begin{tabular}{|c|c|c|c|c|c|c|}
\hline & $\begin{array}{l}\text { IP non- } \\
\text { final } \\
\text { position }\end{array}$ & $\begin{array}{l}\text { IP-final } \\
\text { position }\end{array}$ & $\mathbf{t}$ & df & $\mathbf{p}$ & $\begin{array}{l}\text { The degree } \\
\text { of } \\
\text { lengthening }\end{array}$ \\
\hline \multicolumn{7}{|c|}{ Vowels in closed syllables (vowel + voiced consonant) } \\
\hline Short vowels & 56.32 & 86.88 & 5.10 & 40 & 0.000 & 1.54 \\
\hline Long vowels & 104.36 & 166.82 & 5.72 & 38 & 0.000 & 1.60 \\
\hline \multicolumn{7}{|c|}{ Vowels in closed syllables (vowel + voiceless consonant) } \\
\hline Short vowels & 53.78 & 81.45 & 4.71 & 38 & 0.000 & 1.51 \\
\hline Long vowels & 86.18 & 132.45 & 5.34 & 36 & 0.000 & 1.54 \\
\hline \multicolumn{7}{|c|}{ Vowels in open syllables } \\
\hline Short vowels & 65.06 & 104.13 & 5.91 & 38 & 0.000 & 1.60 \\
\hline Long vowels & 129.58 & 214.67 & 7.02 & 36 & 0.000 & 1.66 \\
\hline
\end{tabular}

In order to examine whether the degree of pre-boundary lengthening depends on the distance between the post-accented word-final vowel and the vowel in the syllable carrying primary stress, we examined separately trisyllabic PWds with primary stress on antepenultimate and penultimate syllable. In this part of the analysis, we analyzed the lengthening of short word-final vowels in open syllables.

${ }^{4}$ The difference in the degree of lengthening between long monophthongs and diphthongs will be discussed in the case of non-final stressed vowels.

${ }^{5}$ Maddieson (1984) points that longer duration of vowels in open syllables has been observed in a large number of languages, including English. Also, the reduction of vocalic duration in front of voiceless consonant is a universal property, which happens due to different intraoral pressure in the production of voiceless and voiced consonants, influencing the speed of transition from vowel to the following consonant (Chen, 1970). 
The results showed almost identical degree of lengthening in both types of PWds, although it is minimally higher in the case of PWds with penultimate stress (Table 2). However, the fact that there is no significant difference in the duration of wordfinal vowels in PWds with antepenultimate and penultimate stress in either IPposition ( $p>0.05$ ), we conclude that the distance of post-accented word-final vowel from the preceding primarily stressed vowel does not affect the degree of lengthening.

Table 2: Duration of English word-final short unstressed vowels in open syllables IP-finally and IP non-finally (ms) in PWds with antepenultimate and penultimate stressed syllables and the degree of pre-boundary lengthening

\begin{tabular}{ccccccc}
\hline $\begin{array}{c}\text { Words with } \\
\text { antepenultimate } \\
\text { stress }\end{array}$ & $\begin{array}{c}\text { IP non- } \\
\text { final } \\
\text { position }\end{array}$ & $\begin{array}{c}\text { IP-final } \\
\text { position }\end{array}$ & $\mathbf{t}$ & df & $\mathbf{p}$ & $\begin{array}{c}\text { The degree } \\
\text { of } \\
\text { lengthening }\end{array}$ \\
\hline Final short vowels & 63.70 & 101.52 & 6.36 & 30 & 0.000 & $\mathbf{1 . 5 9}$ \\
\hline $\begin{array}{c}\text { Words with } \\
\text { penultimate stress }\end{array}$ & $\begin{array}{c}\text { IP non- } \\
\text { final } \\
\text { position }\end{array}$ & $\begin{array}{c}\text { IP-final } \\
\text { position }\end{array}$ & $\mathbf{t}$ & $\mathbf{d f}$ & $\mathbf{p}$ & $\begin{array}{c}\text { The degree } \\
\text { of } \\
\text { lengthening }\end{array}$ \\
\hline Final short vowels & 64.04 & 102.61 & 6.72 & 30 & 0.000 & $\mathbf{1 . 6 0}$ \\
\hline
\end{tabular}

However, in contrast to word-final vowels, post-accented word-medial vowels do not lengthen in English (Table 3). In this part of the analysis, we measured the lengthening of short unstressed vowels. The vowels were followed by both voiced and voiceless consonants and for methodological reasons, the number of vocalic realizations followed by voiced and voiceless consonant was identical in each sample. ${ }^{6}$ The absence of lengthening was also observed in the case of preaccented unstressed vowels in word-initial syllables (Table 4). Thus, in the case of unstressed vowels in English, the analysis shows that only word-final vowels undergo pre-boundary lengthening.

Table 3: Duration of English post-accented word-medial unstressed vowels IP-finally and IP non-finally (ms)

\begin{tabular}{ccccc}
\hline $\begin{array}{c}\text { IP non-final } \\
\text { position }\end{array}$ & $\begin{array}{c}\text { IP-final } \\
\text { position }\end{array}$ & $\mathbf{t}$ & $\mathbf{d f}$ & $\mathbf{p}$ \\
\hline 50.06 & 51.75 & 0.53 & 32 & 0.598 \\
\hline
\end{tabular}

\footnotetext{
${ }^{6}$ The same procedure concerning the number of the following voiced and voiceless consonants was used in the analyses whose results are provided in Table 4, Table 6, Table 10, Table 11 and Table 14.
} 
Table 4: Duration of English pre-accented word-initial unstressed vowels IP-finally and IP non-finally (ms)

\begin{tabular}{ccccc}
\hline $\begin{array}{c}\text { IP non-final } \\
\text { position }\end{array}$ & $\begin{array}{c}\text { IP-final } \\
\text { position }\end{array}$ & t & df & p \\
\hline 49.94 & 52.88 & 1.26 & 32 & 0.216 \\
\hline
\end{tabular}

Shifting the focus to stressed syllables, we first examined non-final vowels in syllables with primary stress. The results of the analysis show relatively low, but significant lengthening (Table 5), which was observed both in PWds with primary stress on antepenultimate and penultimate syllables (Table 6). In addition, significant difference in vowel duration was not found between PWds with these two accentual patterns in either IP-position $(\mathrm{p}>0.05)$, which indicates that the degree of pre-boundary lengthening of vowels in non-final stressed syllables does not depend on their distance from I-boundary.

Table 5: Duration of English non-final stressed vowels IP-finally and IP non-finally (ms) and the degree of pre-boundary lengthening

\begin{tabular}{ccccccc}
\hline & $\begin{array}{c}\text { IP non- } \\
\text { final } \\
\text { position }\end{array}$ & $\begin{array}{l}\text { IP-final } \\
\text { position }\end{array}$ & t & df & p & $\begin{array}{c}\text { The degree } \\
\text { of } \\
\text { lengthening }\end{array}$ \\
\hline Vowels in closed syllable (vowel + voiced consonant) & \\
\hline Short monophthongs & 73.53 & 85.57 & 3.95 & 36 & 0.000 & $\mathbf{1 . 1 6}$ \\
\hline Long monophthongs & 107.44 & 127.11 & 4.55 & 36 & 0.000 & $\mathbf{1 . 1 8}$ \\
\hline Diphthongs & 132.45 & 159.09 & 4.69 & 38 & 0.000 & $\mathbf{1 . 2 0}$ \\
\hline \multicolumn{6}{c}{ Vowels in closed syllable (vowel + voiceless consonant) } \\
\hline Short monophthongs & 69.27 & 79.09 & 3.72 & 34 & 0.001 & $\mathbf{1 . 1 4}$ \\
\hline Long monophthongs & 88.22 & 101.44 & 3.80 & 34 & 0.001 & $\mathbf{1 . 1 5}$ \\
\hline Diphthongs & 105.92 & 122.75 & 3.78 & 36 & 0.001 & $\mathbf{1 . 1 6}$ \\
\hline
\end{tabular}

Table 6: Duration of English non-final stressed vowels IP-finally and IP non-finally (ms) in PWds with antepenultimate and penultimate stressed syllables and the degree of preboundary lengthening

\begin{tabular}{ccccccc}
\hline $\begin{array}{c}\text { Words with } \\
\text { antepenultimate } \\
\text { stress }\end{array}$ & $\begin{array}{c}\text { IP non- } \\
\text { final } \\
\text { position }\end{array}$ & $\begin{array}{c}\text { IP-final } \\
\text { position }\end{array}$ & t & df & p & $\begin{array}{c}\text { The degree } \\
\text { of } \\
\text { lengthening }\end{array}$ \\
\hline Short vowels & 72.07 & 83.82 & 3.98 & 36 & 0.000 & $\mathbf{1 . 1 6}$ \\
\hline Long vowels & 107.89 & 126.29 & 4.08 & 38 & 0.000 & $\mathbf{1 . 1 7}$ \\
\hline $\begin{array}{c}\text { Words with } \\
\text { penultimate } \\
\text { stress }\end{array}$ & $\begin{array}{c}\text { IP non- } \\
\text { final } \\
\text { position }\end{array}$ & $\begin{array}{c}\text { IP-final } \\
\text { position }\end{array}$ & $\mathbf{t}$ & df & $\mathbf{p}$ & $\begin{array}{c}\text { The degree } \\
\text { of } \\
\text { lengthening }\end{array}$ \\
\hline Short vowels & 71.33 & 81.20 & 3.92 & 36 & 0.000 & $\mathbf{1 . 1 4}$ \\
\hline Long vowels & 110.74 & 129.86 & 4.19 & 38 & 0.000 & $\mathbf{1 . 1 7}$ \\
\hline
\end{tabular}


Lastly, we examined the lengthening of stressed vowels in word-final syllables. Due to corpus limitations caused by the features of stress-carrying suffixes in English, it was possible to analyze only long vowels, i.e. long monophthongs and diphthongs. The results point to rather significant lengthening, which is slightly higher in comparison to final post-accented vowels (cf. Table 1 and Table 7). This only shows that it is the finality of a syllable that is crucial to lengthening, whereas the prominence of F0 only slightly increases the degree of this process.

Table 7: Duration of English word-final stressed vowels (ms) IP-finally and IP non-finally (ms) and the degree of pre-boundary lengthening

\begin{tabular}{ccccccc}
\hline & $\begin{array}{c}\text { IP non- } \\
\text { final } \\
\text { position }\end{array}$ & $\begin{array}{l}\text { IP-final } \\
\text { position }\end{array}$ & t & df & p & $\begin{array}{c}\text { The degree } \\
\text { of } \\
\text { lengthening }\end{array}$ \\
\hline Vowels in closed syllables (vowel + voiced consonant) & \\
\hline Long monophthongs & 125.92 & 199.77 & 5.71 & 30 & 0.000 & $\mathbf{1 . 5 9}$ \\
\hline Diphthongs & 152.09 & 246.38 & 6.14 & 32 & 0.000 & $\mathbf{1 . 6 2}$ \\
\hline \multicolumn{7}{c}{ Vowels in open syllables } \\
\hline Long monophthongs & 128.45 & 206.08 & 6.13 & 30 & 0.000 & $\mathbf{1 . 6 0}$ \\
\hline Diphthongs & 156.42 & 259.57 & 7.08 & 30 & 0.000 & $\mathbf{1 . 6 6}$ \\
\hline
\end{tabular}

\subsection{I-boundary lengthening of Serbian vowels}

In the case of Serbian post-accented word-final syllables, it was possible to examine only the duration of short vowels due to the fact that long vowels are not found in this position (Table 8). ${ }^{7}$ Although the results point to a lower degree of pre-boundary lengthening than in English (cf. Table 1 and Table 8), the relation between the degree of lengthening and vowel duration follows the same pattern as in English. Thus, the degree of pre-boundary lengthening is the most prominent in open syllables, less in syllables with a voiced coda consonant, and yet less in those with a voiceless coda consonant.

Moreover, no statistically significant difference between word-final vowel duration was found in $\mathrm{PWds}$ containing stressed antepenultimate and stressed ultimate syllable in either IP-position ( $p>0.05$ ), which indicates that in Serbian, as in English, the distance of the final unstressed vowel from the preceding stressed

\footnotetext{
${ }^{7}$ This observation refers only to phonologically distinctive length, i.e. stressed vowels with short and long accents, and not to so-called 'post-accentual lengths' in Serbian.
} 
vowel in PWds does not influence the degree of pre-boundary lengthening (Table 9). ${ }^{8}$

Table 8: Duration of Serbian post-accented word-final unstressed vowels IP-finally and IP non-finally (ms) and the degree of pre-boundary lengthening

\begin{tabular}{|c|c|c|c|c|c|c|}
\hline & $\begin{array}{l}\text { IP non- } \\
\text { final } \\
\text { position }\end{array}$ & $\begin{array}{l}\text { IP-final } \\
\text { position }\end{array}$ & $\mathbf{t}$ & df & $\mathbf{p}$ & $\begin{array}{c}\text { The degree } \\
\text { of } \\
\text { lengthening }\end{array}$ \\
\hline \multicolumn{7}{|c|}{ Vowels in closed syllables (vowel + voiced consonant) } \\
\hline Short vowels & 61.07 & 88.14 & 5.17 & 34 & 0.000 & 1.44 \\
\hline \multicolumn{7}{|c|}{$\begin{array}{l}\text { Vowels in closed syllables (vowel + voiceless consonant) } \\
\end{array}$} \\
\hline Short vowels & 57.43 & 81.64 & 5.33 & 36 & 0.000 & 1.42 \\
\hline \multicolumn{7}{|c|}{ Vowels in open syllables } \\
\hline Short vowels & 66.31 & 100.38 & 7.03 & 48 & 0.000 & 1.51 \\
\hline
\end{tabular}

Table 9: Duration of Serbian word-final short unstressed vowels in open syllables IP-finally and IP non-finally (ms) in PWds with antepenultimate and penultimate stressed syllables and the degree of pre-boundary lengthening

\begin{tabular}{ccccccc}
\hline $\begin{array}{c}\text { Words with } \\
\text { antepenultimate } \\
\text { stress }\end{array}$ & $\begin{array}{c}\text { IP non- } \\
\text { final } \\
\text { position }\end{array}$ & $\begin{array}{c}\text { IP-final } \\
\text { position }\end{array}$ & t & df & p & $\begin{array}{c}\text { The degree } \\
\text { of } \\
\text { lengthening }\end{array}$ \\
\hline Short vowels & 64.17 & 96.13 & 6.63 & 30 & 0.000 & $\mathbf{1 . 5 0}$ \\
\hline $\begin{array}{c}\text { Words with penultimate } \\
\text { stress }\end{array}$ & $\begin{array}{c}\text { IP non- } \\
\text { final } \\
\text { position }\end{array}$ & $\begin{array}{c}\text { IP-final } \\
\text { position }\end{array}$ & t & df & p & $\begin{array}{c}\text { The degree } \\
\text { of } \\
\text { lengthening }\end{array}$ \\
\hline Short vowels & 65.01 & 98.29 & 6.87 & 30 & 0.000 & $\mathbf{1 . 5 1}$ \\
\hline
\end{tabular}

Unlike English, the analysis of the duration of vowels in post-accented medial syllables revealed that they do undergo pre-boundary lengthening in Serbian (Table 10). These results further indicate that English and Serbian differ with respect to the scope of pre-boundary lengthening.

\footnotetext{
${ }^{8}$ Sovilj-Nikić (2007: 48-49) finds the tendency of Serbian unstressed vowels to last longer if they are closer to stressed syllables. In this analysis, statistically significant difference in vowel duration with respect to the distance from the stressed syllable was not found. However, it is possible that the analysis of longer words would give different results.
} 
Table 10: Duration of Serbian post-accented short word-medial unstressed vowels IP-finally and IP non-finally (ms) and the degree of pre-boundary lengthening

\begin{tabular}{cccccc}
\hline $\begin{array}{c}\text { IP non-final } \\
\text { position }\end{array}$ & $\begin{array}{c}\text { IP-final } \\
\text { position }\end{array}$ & $\mathbf{t}$ & $\mathbf{d f}$ & $\mathbf{p}$ & $\begin{array}{c}\text { The degree } \\
\text { of } \\
\text { lengthening }\end{array}$ \\
\hline 57.93 & 69.11 & 2.42 & 34 & 0.021 & $\mathbf{1 . 1 9}$ \\
\hline
\end{tabular}

As for pre-accented word-initial unstressed vowels, English and Serbian show the same behavior. Thus, pre-accented initial realizations of Serbian vowels are not affected by the process of lengthening (Table 11). In this part of the analysis we examined only short unstressed vowels.

Table 11: Duration of Serbian pre-accented short word-initial unstressed vowels IP-finally and IP non-finally (ms)

\begin{tabular}{ccccc}
\hline $\begin{array}{c}\text { IP non-final } \\
\text { position }\end{array}$ & $\begin{array}{c}\text { IP-final } \\
\text { position }\end{array}$ & $\mathbf{t}$ & df & $\mathbf{p}$ \\
\hline 57.27 & 60.32 & 0.86 & 52 & 0.394 \\
\hline
\end{tabular}

Lastly, significant lengthening was also observed in the case of Serbian non-final stressed vowels (Table 12). However, in contrast to post-accented final vowels, which exhibit higher lengthening in English, the degree of lengthening of non-final stressed vowels is higher in Serbian (cf. Table 6 and Table 13). It can be concluded that pre-boundary lengthening in Serbian starts on the stressed syllable of PWd in front of I-boundary, finishes on the ultimate syllable of the PWd in question, where it is the highest, and it affects all the vowels in between, in contrast to English where these vowels are skipped by the process of lengthening. However, as in English, significant difference in lengthening was not found between stressed vowels in antepenultimate and penultimate syllables (Table 13) considering that that the difference in duration of both short and long vowels was not statistically significant either IP-position ( $\mathrm{p}>0.05)$.

Table 12: Duration of Serbian non-final stressed vowels IP-finally and IP non-finally (ms) and the degree of pre-boundary lengthening

\begin{tabular}{ccccccc}
\hline & $\begin{array}{c}\text { IP non- } \\
\text { final } \\
\text { position }\end{array}$ & $\begin{array}{c}\text { IP-final } \\
\text { position }\end{array}$ & t & df & p & $\begin{array}{c}\text { The degree } \\
\text { of } \\
\text { lengthening }\end{array}$ \\
\hline Vowels in closed syllables (vowel + voiced consonant) & \\
\hline Short vowels & 87.07 & 110.05 & 4.16 & 36 & 0.000 & $\mathbf{1 . 2 6}$ \\
\hline Long vowels & 122.13 & 160.69 & 5.02 & 34 & 0.000 & $\mathbf{1 . 3 2}$ \\
\hline Vowels in closed syllables (vowel + voiceless consonant) & \\
\hline Short vowels & 84.96 & 105.65 & 4.08 & 34 & 0.000 & $\mathbf{1 . 2 4}$ \\
\hline Long vowels & 118.09 & 153.67 & 4.82 & 34 & 0.000 & $\mathbf{1 . 3 0}$ \\
\hline
\end{tabular}


Table 13: Duration of Serbian non-final stressed vowels IP-finally and IP non-finally (ms) in PWds with antepenultimate and penultimate stressed syllables and the degree of preboundary lengthening

\begin{tabular}{ccccccc}
\hline $\begin{array}{c}\text { Words with } \\
\text { antepenultimate } \\
\text { stress }\end{array}$ & $\begin{array}{c}\text { IP non- } \\
\text { final } \\
\text { position }\end{array}$ & $\begin{array}{c}\text { IP-final } \\
\text { position }\end{array}$ & t & df & p & $\begin{array}{c}\text { The degree } \\
\text { of } \\
\text { lengthening }\end{array}$ \\
\hline Short vowels & 87.46 & 107.67 & 4.10 & 32 & 0.000 & $\mathbf{1 . 2 3}$ \\
\hline Long vowels & 122.36 & 161.11 & 4.87 & 32 & 0.000 & $\mathbf{1 . 3 2}$ \\
\hline $\begin{array}{c}\text { Words with } \\
\text { penultimate } \\
\text { stress }\end{array}$ & $\begin{array}{c}\text { IP non- } \\
\text { final } \\
\text { position }\end{array}$ & $\begin{array}{c}\text { IP-final } \\
\text { position }\end{array}$ & $\mathbf{t}$ & $\mathbf{d f}$ & $\mathbf{p}$ & $\begin{array}{c}\text { The degree } \\
\text { of } \\
\text { lengthening }\end{array}$ \\
\hline Short vowels & 89.35 & 110.53 & 4.18 & 32 & 0.000 & $\mathbf{1 . 2 4}$ \\
\hline Long vowels & 121.47 & 157.05 & 4.63 & 32 & 0.000 & $\mathbf{1 . 2 9}$ \\
\hline
\end{tabular}

\section{CONCLUSIONS}

Our analysis shows that the degree of I-boundary lengthening of vowels is rather similar in English and Serbian. In the case of final unstressed syllables, it is slightly higher in English, whereas in the case of non-final stressed syllables, it is slightly higher in Serbian. Also, the process of pre-boundary lengthening does not affect pre-accented unstressed vowels in either English or Serbian. The last similarity between English and Serbian concerns the degree of lengthening of nonfinal stressed vowels depending on the position in a prosodic word, i.e. distance from I-boundary as well as the degree of lengthening of final unstressed vowels depending on their closeness to the primary stress in a prosodic word. In both cases, the significant relation was not found in either English or Serbian.

However, the differences were found in relation to the scope of lengthening in these two languages. While the scope lengthening in Serbian starts on the last stressed syllable of IP-final PWd and continues until the ultimate syllable, English non-final unstressed vowels following stressed vowels are skipped by this process (Figure 1) ${ }^{9}$. We conclude that lengthening tends to be slightly more significant in Serbian, indicating that low F0 prominence might be compensated for a larger scope of I-boundary lengthening.

\footnotetext{
${ }^{9}$ The same domain of pre-boundary lengthening was found by Shattuck-Hufnagel - Turk (1998) and Turk - Shattuck-Hufnagel (2007) in American English.
} 
Figure 1: The degree of lengthening of short vowels in closed syllables in trisyllabic PWds in English and Serbian ${ }^{10}$

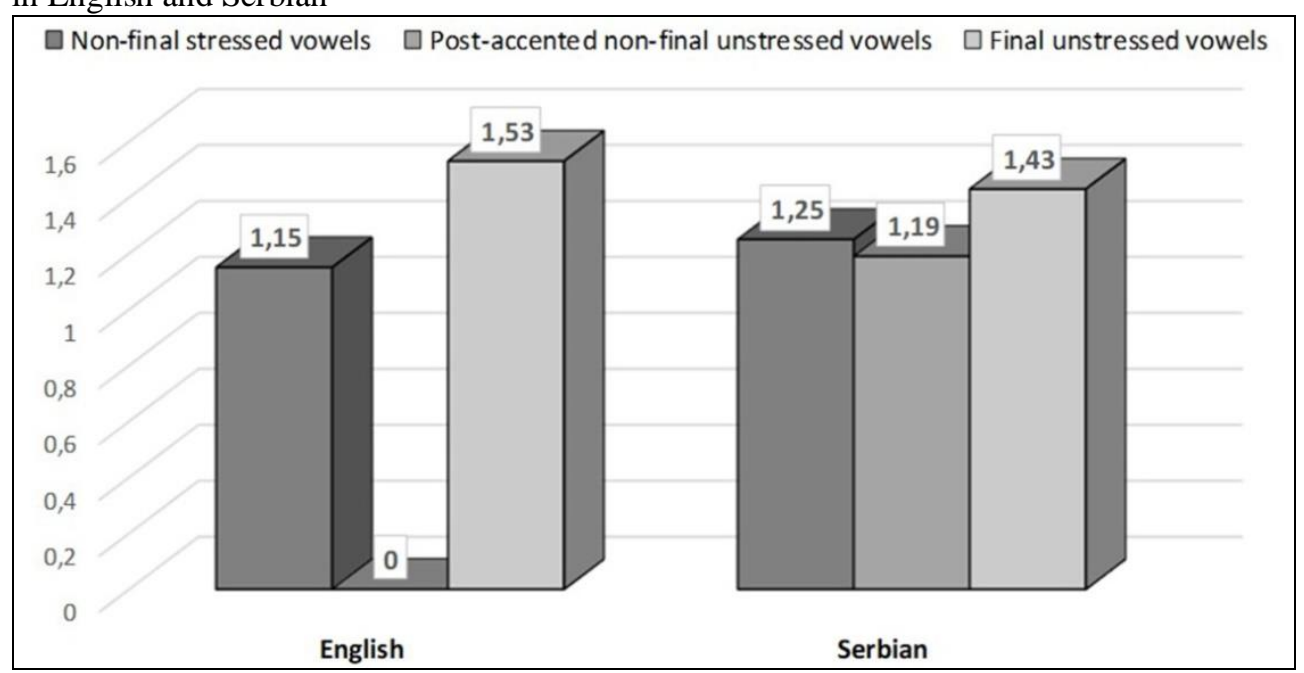

Future research should involve testing the results by examining the speech produced by a larger number of subjects as well as testing the perceptual relevance of I-boundary lengthening of vowels in IPs with final information focus in English and Serbian.

Bojana Jakovljević, Maja Marković

\section{ODLIKE FINALNOG DUŽENJA VOKALA U INTONCIJSKIM FRAZAMA U ENGLESKOM I SRPSKOM JEZIKU}

\section{Rezime}

Engleski i srpski jezik značajno se razlikuju u pogledu prominentnosti pokazatelja desne IP granice. Dok u engleskom jeziku finalni informacioni fokus odlikuje veliki raspon osnovnog tona, te se granični tonovi mogu smatrati pouzdanim pokazateljem desne IP granice, $u$ srpskom jeziku granični tonovi su informativni samo u slučaju uzlazne intonacije, te se srpski jezik prvenstveno služi temporalnim odlikama segmenata, odnosno procesom finalnog duženja, kako bi se naznačila desna IP granica. Budući da je finalno duženje univerzalan proces, te da je prisutan u oba jezika, glavni cilj ovog istraživanja jeste da utvrdi stepen i opseg finalnog duženja u engleskom i srpskom jeziku. Šire gledano, istraživanje

\footnotetext{
${ }^{10}$ In the case of all vocalic realizations, the number of vowels followed by a voiced and voiceless consonant was identical in both languages.
} 
ima za cilj da analizira odnos ova dva pokazatelja desne IP granice, odnosno da ispita da li se odsusutvo informativnosti graničnih tonova u slučaju silazne intonacije u srpskom jeziku kompenzuje većom prominentnošću finalnog duženja. Budući da analiza data u ovom radu predstavlja deo znatno opširnije eksperimentalne korpusne studije koja se bavi temporalnim odlikama segmenta na granicama prozodijskih celina u engleskom i srpskom jeziku, govorni korpusi u oba jezika bili su prilično veliki i obuhvatali su oko jedan sat čitanog govora. Tekstove su čitale jedna izvorna govornica engleskog i jedna izvorna govornica srpskog jezika, pri čemu su obe profesionalni spikeri, a korpusi su bili uporedivi u pogledu brzine artikulacije, tematike i kvaliteta snimaka. Analiza data u ovom radu fokusira se na finalno duženje vokala u trosložnim rečima u engleskom i srpskom jeziku. Mereno je njihvo trajanje u IP finlanoj i IP nefinalnoj poziciji u programu Praat (verzija 6.0.52), a potom je izveden stepen finalnog duženja. Svi rezultati merenja statistički su obrađeni. Rezultati analize pokazali su da se engleski i srpski jezik ne razlikuju bitno u pogledu stepena duženja. Iako je $\mathrm{u}$ engleskom duženje nešto veće kod vokala u finalnim nenaglašenim slogovima, u srpskom je duženje veće kod vokala u nefinalnim naglašenim slogovima. Mnogo veće i bitnije razlike primećene su u opsegu duženja u ova dva jezika. Dok u srpskom jeziku finalno duženje utiče na sve vokale, počevši od nefinalnog naglašenog do finalnog nenaglašenog vokala prozodijske reči pred IP granicom, te se odvija kontinuirano, odnosno bez prekida, u engleskom jeziku postakcentovani nenaglašeni medijalni vokali ne podležu duženju. Drugim rečima, u engleskom je proces finalnog duženja nekontinuiran budući da finalno duženje utiče na naglašene i finalne vokale prozodijskih reči pred IP granicom, a svi vokali između, ukoliko su prisutni, bivaju preskočeni. Stoga, rezultati ove analize sugerišu da je proces finalnog duženja nešto prominentniji u srpskom nego u engleskom jeziku, što se može posmatrati kao kompenzacija odsustva informativnosti graničnih tonova u intonacijskim frazama u srpskom jeziku.

Ključne reči: finalno duženje, intonacijska fraza, prozodijska reč, sintaksičko-prozodijski interfejs, engleski jezik, srpski jezik, akustička analiza

\section{REFERENCES}

Beckman, M. - Pierrehumbert, J. (1986). Intonational Structure in Japanese and English. Phonology Yearbook, 3, 255-310.

Berkovitz, R. (1994). Durational effects in final lengthening, gapping and contrastive stress. Language and speech, 37(3), 237-250.

Boersma, P. - Weenink, D. (2019). Praat: doing phonetics by computer (Version 6.0.52). Downloaded 2 May 2019 from http://www.praat.org

Byrd, D. - Saltzman, E. (2003). The elastic phrase: Modeling the dynamics of boundary-adjacent lengthening. Journal of Phonetics, 31, 149-180.

Cambier-Langeveld, T. - Nespor, M. \& van Heuven, V. J. (1997). The domain of final lengthening in the production of Dutch. In: Coerts, J. A. \& de Hoop, 
H. (eds.) (1997). Linguistics in the Netherlands. Amsterdam: John Benjamins. 13-24.

Campione, E. - Véronis, J. (2002). A Large-Scale Multilingual Study of Silent Pause Duration. In: Bel, B \& Marlien, I. (eds.) (2002). Proceedings of the Speech Prosody 2002 conference. Aix-en-Provence: Laboratoire Parole et Langage. 192-202.

Chen, M. (1970). Vowel length variation as a function of the voicing of the consonant environment. Phonetica, 22, 129-159.

Chow, I. (2008). Quantitative analysis of pre-boundary lengthening in Cantonese. In: Barbosa, P. A.-Madureira, S. \& Reis, C. (eds.) (2008). Proceedings of the 4th International Conference on Speech Prosody [online]. Downloaded $30 \quad$ November 2018 from https://www.iscaspeech.org/archive/sp2008/papers/sp08_543

Cruttenden, A. (1986). Intonation. Cambridge: Cambridge University Press.

Elordieta, G. - Frota, S. \& Vigário, M. (2005). Subjects, objects and intonational phrasing in Spanish and Portuguese. Studia Linguistica, 59(2/3), 110143.

Godjevac, S. (2000). Intonation, Word Order and Focus Projection in SerboCroatian (Unpublished doctoral dissertation). Ohio State University, Columbus, Ohio USA.

Godjevac, S. (2005). Transcribing Serbo-Croatian intonation. In: Jun, S.-A. (ed.) (2006). Prosodic Typology: The Phonology of Intonation and Phrasing. Oxford: Oxford University Press. 146-171.

Goldman-Eisler, F. (1961). The significance of changes in the rate of articulation. Language and Speech, 4(4), 171-174.

Horne, M. - Strangert, E. \& Heldner, M. (1995). Prosodic boundary strength in Swedish: Final lengthening and silent interval duration. In: Kjell, E. \& Branderud, P. (eds.) (1995). Proceedings of the 13th International Congress of Phonetic Sciences. Stockholm: Royal Institute of Technology. 170-173.

Inkelas, S. - Zec, D. (1993). Auxiliary reduction without empty categories: a prosodic account. Working Papers of the Cornell Phonetics Laboratory, 8, 205-253.

Ivić, P. - Lehiste, I. (1996). Prozodija reči i rečenice u srpskohrvatskom jeziku. Novi Sad: Izdavačka knjižarnica Zorana Stojanovića. (published in Cyrillic) Klatt, D. H. (1975). Vowel lengthening is syntactically determined in a connected discourse. Journal of Phonetics, 3, 129-140. 
Klatt, D. H. (1976). Linguistic uses of segmental duration in English: Acoustic and perceptual evidence. Journal of the Acoustical Society of America, 59, 1208-1221.

Kohler, K. J. (1983). Prosodic boundary signals in German. Phonetica, 40, 89-134.

Ladd, D. R. (1996). Intonational Phonology. Cambridge: Cambridge University Press.

Maddieson, I. (1984). Phonetic cues to syllabification. UCLA Working Papers in Phonetics, 59, 85-101.

Marković, M. - Milićev, T. (2012). Clitic placement and the properties of the Intonational Phrase in Serbian. In: Halupka-Rešetar, S.-Marković, M.Milićev, T. \& Milićević, N. (eds.) (2012). Selected papers from the 3rd International Conference on Syntax, Phonology and Language Analysis (SinFonIJA 3). Cambridge: Cambridge Scholar Publishing. 175-205.

Nespor, M. - Vogel, I. (1986). Prosodic Phonology. Foris: Dordrecht.

Oller, D. K. (1973). The effect of position in utterance on speech segment duration in English. Journal of the Acoustical Society of America, 54, 1235-1247.

Selkirk, E. (1984). Phonology and syntax: The relation between sound and structure. Cambridge, MA: MIT Press.

Selkirk, E. (1986). On Derived Domains in Sentence Phonology. Phonology Yearbook, 3, 371-405.

Selkirk, E. (1996). The prosodic Structure of Function Words. In: Demuth, K. \& Morgan, J. L. (eds.) (1996). Signal to Syntax: Bootstrapping from Speech to Grammar in Early Acquisition. Mahwah NJ: Lawrence Erlbaum. 187-213.

Selkirk, E. (2005). Comments on the Intonational Phrasing in English. In: Frota, S, Vigário, M. \& Freitas, M. J. (eds.) (2005). Prosodies. Berlin: Mouton de Gruyter. 11-58.

Shattuck-Hufnagel, S. - Alice Turk, A. (1998). The domain of phrase-final lengthening in English. Journal of the Acoustical Society of America, 102(2), 1235-1236.

Shepherd, M. A. (2008). The scope and effects of preboundary prosodic lengthening in Japanese. USC Working Papers in Linguistics, 4, 1-14.

Sovilj-Nikić, S. (2007). Trajanje vokala kao jedan od prozodijskih elemenata u sintezi govora na srpskom jeziku (Unpublished master's thesis). Fakultet tehničkih nauka, Univerzitet u Novom Sadu, Novi Sad.

Sredojević, D. (2011). Eksperimentalno-fonetsko ispitivanje prozodijskih karakteristika novosadskog govora (Unpublished doctoral dissertation). 
Filozofski fakultet, Univerzitet u Novom Sadu, Novi Sad. (published in Cyrillic)

Turk, A. - Shattuck-Hufnagel, S. (2007). Multiple targets of phrase-final lengthening in American English Words. Journal of Phonetics, 35, 445472.

Volskaya, N. - Stepanova, S. (2004). On the temporal component of intonational phrasing. In: Speech Informatics Group of SPIIRAS (eds.) (2004). Proceedings of the 9th International Conference on Speech and Computer (SPECOM 2004). Saint Petersburg: House Anatolya. 641-644.

Wang, M. Q. - Julia Hirschberg, J. (1992). Automatic Classification of Intonational Phrase Boundaries. Computer Speech and Language, 6, 175-196.

Wightman, C.-Shattuck-Hufnagel, S.-Ostendorf, M. \& Price, P. (1992). Segmental durations in the vicinity of prosodic phrase boundaries. Journal of the Acoustical Society of America, 91, 1707-1717.

Zec, D. (2002). On the Prosodic Status of Function Words. Working Papers of the Cornell Phonetics Laboratory, 14, 207-249. 